\title{
POLITICAL-ECONOMIC CYCLE MODELS OF ECONOMY OF GREECE
}

\author{
Andrea TKÁČOVÁ ${ }^{1 \mathbb{D}}$, Beáta GAVUROVÁ ${ }^{2^{+(\mathbb{D})}}$, Viliam KOVÁČ ${ }^{(\mathbb{D}}$ \\ ${ }^{1}$ Department of Finance, Faculty of Economics, Technical University of Košice, \\ Košice, Slovak Republic \\ ${ }^{2}$ Department of Banking and Investment, Faculty of Economics, \\ Technical University of Košice, Košice, Slovak Republic
}

Received 30 August 2018; accepted 14 November 2018

\begin{abstract}
The political-economic cycle can be caused as the consequence of the wrong political decisions, made with the aim of re-election and maintaining the political power. These decisions influence the macroeconomic indicators of the country and their presence is problematic in the advanced economies. The main objective of this study is to verify the existence of the politicaleconomic cycle model in the case of Greece and to identify the type of this cycle. The basement is given by the approach of Alesina and Roubini (1992), which observes the relationship between the political dummy variables and the selected macroeconomic variables such as gross domestic product, unemployment rate and inflation rate. The eight linear regression models are developed in the R software environment, while the three of them are opportunistic and the five are ideological. These models are identified as statistically significant and according to the methodology, tested for the presence of serial correlation, heteroscedasticity and residual normality. As the models do not confirm the presence of an opportunistic or ideological political-economic cycle, according to the data, the influence of the political parties on changes in the macroeconomic variables before the election is not proved for the case of Greece.
\end{abstract}

Keywords: political-economic cycle, political spectrum, gross domestic product, unemployment, inflation, regression analysis, opportunistic model, ideological model, Greece.

JEL Classification: C32, E60.

\section{Introduction}

The term political-economic cycle is closely related to the perception of politicians, as rational individuals seeking to maximise their benefits. As stated by Musgrave (1994), in this case, the re-election of a ruling political party is beneficial. The basic prerequisite for the existence of political-economic cycle is the fact that political power has an impact on the development of the economy. Another prerequisite is that electors choose on the basis of the economic

${ }^{\star}$ Corresponding author. E-mail: beata.gavurova@tuke.sk 
variables. The relationship between the economic cycle and the political cycle without this assumption cannot be valid. The ruling party has its own fiscal policy decisions to influence electors. And by influencing the macroeconomic variables, it can increase its chances of reelection to such an extent that electors become aware of it.

The issue of political-economic cycle began to resonate in the economic literature from the late seventieth years of the twentieth century. Its main technical platform was the construction of models to capture political-economic process with its subsequent testing in the specific economic and political conditions. The basement of the theory is lies in the four elementary models of the political-economic cycle, whose essence is a trade-off relationship between inflation and unemployment, expressed by the Phillips curve. An important differentiation aspect is a view of electors and political parties (Kliková \& Kotlán, 2006; Mura, \& Machyniak, 2014). The parties are divided into the two opposite groups - opportunistic ones and ideological ones. The opportunistic parties try to maximise the benefit of the given situation as a whole for all the electors, while the ideological parties focus on their ideology and mainly on their electors. The electors are distinguished into the two groups too - rational ones and non-rational ones. The rational electors are able take into account all available information in the decision making process, while the non-rational electors do not have this ability.

The Nordhaus model from 1975 is based on the assumption of the existence of the opportunistic parties and the non-rational electors. There is a clear description of pre-electoral expansion for this type. It means that unemployment rate is reduced and inflation is increased immediately before the election. Regarding the type of the electors and type of the parties, the fiscal expansion took place with the same success before the further election. The second model is the Hibbs model from 1977 that is based on the assumption of a combination of the ideological parties and the irrational electors. Its author considers the existence of the systematic and lasting differences in unemployment and inflation depending on the political orientation of the government. Rogoff and Sibert (1998) represent the rational opportunistic model based on the assumption of the rational electors and the opportunistic parties. If the electors are rational, the government cannot positively influence the real dimensions. And hence, in the case of an expansive economic policy, inflation is able only to rise before the election. The rational ideological model is conceived on the basement of a combination of the rational electors and the ideological parties. Alesina (1987) and then Alesina and Sachs (1988) empirically confirm them in their works. The present economic theory has yet another classification of the political-economic cycle models based on the a cycle and on the $\beta$ cycle. The a cycle is also referred to as the machiavelistic cycle. It is characterised by the fact that it is caused by the unambiguous manipulation of the country's economy led by the government, which is also a prerequisite for its existence. The Nordhaus model can be included in this cycle type too. The $\beta$ cycle arose as a result of the election when another political party appeared in the government. It is the result of trying to fulfil the different goals of the political parties and it is not caused by conscious manipulation with the economy. That is why, it is considered to be the weaker political-economic cycle type. The Hibbs model can be an instance of this (Pủbal \& Vitek, 2003). Drazen (2000) is the first major critic of the basic political-economic cycle models with a preference of criticism based on non-rationality - he 
criticises the Nordhaus model and the Hibbs model. Electors do not want the government to be re-elected if they know that the election will follow a period of higher unemployment rate and higher inflation rate. According to Drazen (2000), all the models have the three major drawbacks - they expect the economy to move after the Phillips curve, monetary policy is considered to be the main driving force in explaining the political-economic cycle and monetary policy is in the hands of the politicians, which does not correspond to the real behaviour of the central bank independent of the election. He also highlights the existence of highly independent central banks of the most economies analysed in the political-economic cycle theory. This idea can be extended in the terms of the European Union circumstances by an existence of the utmost autonomy of the central bank from the policies of the euro area member countries.

\section{Overview of the research studies in the field of the political-economic cycle theory}

The Nordhaus model (1975) and the Hibbs model (1977) can be included in the first generation of the electoral cycles, often referred to as the original political-economic cycle models. The second generation of the electoral models consists of the already mentioned rational opportunistic models (Rogoff, 1990) and the rational ideological models (Alesina, 1987), which are based on the unfavourable selection and the signalling behaviour. Instead of the fluctuating macroeconomic variables, they deal with the changes in the fiscal policy. They are also called the models of the political-budget cycle.

The study of Alesina and Roubini (1992) is considered to be one of the most famous. The authors test the economies of the eighteen Organisation for Economic Co-operation and Development member countries in the period from 1960 to 1987. Their traditional approach tracks the impact and influence of the electoral cycle on the development of real economy output, unemployment and inflation. They conclude that the electoral cycle affects the individual macroeconomic indicators. According to many authors, this model is already outdated and cannot fully take into account all the factors that affect the individual macroeconomic indicators. The essence of this model was used by Štiková (2007) for a case of the Czech Republic. The study shows that ideological features in the behaviour of the Czech politicians are not confirmed. The author states that the existence of the opportunistic behaviour of the government also reflects the development of the selected public budget expenditure items within the electoral cycle and the evolution of the cyclically-adjusted deficit after 2000. Galeotti and Salford (2001) also based their model upon the Alesina and Roubini study and their model is complemented by the second policy variable. On this basis, it is possible to examine the development of the macroeconomic indicators before the election, but also regarding the second artificial political variable in the post-electoral period, it should lead to a gross domestic product decrease, an unemployment rate increase and an inflation reduction. The study aims to reveal the existence of a pre-electoral cycle in the fiscal variables of the explored countries in the time period from 1961 to 1995 . The expectations are an increase of public spending and deficit and a decrease of the tax burden during the electoral period. 
Haan and Klomp (2013) report that the most studies devoted to the political-budget cycle theory are often based on the assumption that cycles do not differ depending on the country. However, the latest studies acknowledge the relatively high heterogeneity of the cycle, which arises as a result of the different conditional factors - a level of country's development, institutional quality, democracy, electoral rules, government form, transparency of the political process and a level of the fiscal rules (Janků, 2016).

The political-budget models are also criticised. A reflection on this critique has led to the emergence of the new models by Persson and Tabellini (2000), Shi and Svensson (2006), Calvo, Chang, and Hellwig (2017), Garmann (2017), and Chrysanthou and Guilló (2018). They are included in the third generation of the electoral cycles and the authors consider the problem of moral hazard as a starting point. Shi and Svensson (2002) state that, unlike the previous approaches in their models, there is a premise that neither electors nor politicians can directly observe a level of the policy competence. This means that politicians cannot be sure how well they are able to transform government revenue into government spending ex ante (Janků, 2016). The electors are rational and make their decisions with respect to the level of competence of the candidate. The empirical study tests the occurrence of the politicalbudget cycle in the different countries, especially at the transnational level. The presence of the most pronounced political-budget cycles is confirmed in the underdeveloped economies and in the less developed countries, with the presence of these cycles being confirmed both in the countries with a democratic system and in the countries with an undemocratic form of government. The other significant studies, whose conclusions have contributed significantly to the political-economic cycle theory, include Brender and Drazen (2005). The aim of the authors is to verify the hypothesis that the existence of political-budget cycle is a phenomenon of mainly new democracies. They include the countries that have not yet made more than three elections since the transition of the regime to democracy. On the basis of the empirical results, it is argued that a strong political-budget cycle exists in the countries marked as new democracies with a clear lack of democracy and short democratic tradition. This is motivated by the inexperience of electors and the resulting policy tendency to influence the budget before the election. Drazen and Elseva (2010) claim that in some countries the political-budget cycle may not be visible at first glance. This is the case if politicians only shift government spending to meet the needs of a certain group of electors. Tujula and Wolswijk (2007) show that political-economic cycle does not have to arise only in the emerging countries or the countries marked as new democracies. In the period from 1970 to 2002, they found the political-economic cycle in the 22 Organisation for Economic Cooperation and Development member countries where the fiscal deficit in the election year increased significantly by $0.3 \%$ of gross domestic product on average. A similar outcome as an instance of one country is shown by Villarreal and Bielma (2017). Alt and Lassen (2006) study the 19 advanced Organisation for Economic Co-operation and Development member countries in the period from 1989 to 1998 with the long democratic strategy and they find that the statistically and economically significant budget cycle exists in some of them. According to this study, particularly, the countries with low public policy transparency and politically polarised countries belong here. Klomp and Haan (2012) test the data of the 65 democratic countries in the period between 1975 and 2005 applying the pooling regression 
model. The authors, through the analysis, confirm the hypothesis that the efforts of the ruling parties to create the political-economic cycle or the political-budget cycle actually lead to influence the elections - to a better electoral result. They also refer to the fact that not only in the most countries the fiscal policy is influenced before the elections, but the influence itself also has a statistically significant positive influence on the electoral support of the ruling parties. In 2013, Jankůs study (2013) was published, analysing the political-economic cycle of the Czech Republic. The author creates the eight linear regression models that are estimated using the least squares method and statistically, econometrically and economically verified. As the most important fact arising from the results of this study the existence of the political-economic cycle in the Czech Republic that is evident can be considered. The Nordhaus model, chronologically the oldest one with the adaptive expectations of the electors and the opportunistic parties, is most often confirmed. At the five-per-cent significance level, it is confirmed that an increase in the gross domestic product growth rate accelerates before the elections, which may indicate the targeted influence of the macroeconomic aggregates by the government - particularly by the governmental policies (Janků, 2013). In the following study, Janků (2016) addresses the conditional political-budget cycle in the Organisation for Economic Co-operation and Development countries. There is the very significant politicalbudget cycle in the countries with a lower level of transparency and credibility - confirmed by deficits in public finances, government expenditures and revenues.

\section{Economic and politic situation in Greece}

For the characteristics of the country economic cycle, gross domestic product growth is most commonly applied indicator. There are several milestones in the development of the Greek gross domestic product values. The first one lies the ninetieth years of the twentieth century, when major indebtedness of the country economy began. The left-wing government formed by the Panhellenic Socialist Movement party took a majority in the parliament in 1996. Its effort to ensure a high living standard of the population had a high share of rising state spending that the country could not afford. The increase in government spending had a positive influence on the development of gross domestic product and employment rate, albeit it negatively affected indebtedness of the country. Hence, the country failed to meet the convergence criteria in 1998 to enter the euro area. In 2001, Greece managed to improve the economy state outwardly and thus, it adopted the new currency - euro. Since then, the economy has had an unrestricted access to cheaper loans to finance its spending, which was reflected in the gross domestic product growth. Moreover, the economy appeared to be healthy and rapidly developing, but the indebtedness of the country grew above $100 \%$ of gross domestic product (Patrikios \& Karyotis, 2008). This growth trend lasted until 2008, when the global financial and economic crisis absolutely battered and the economy landed in a recession. The decline in foreign direct investment and the overall drop in tourism interest meant a significant decrease in gross domestic product. Against this backdrop, a much bigger problem has begun to emerge, and this was the country's inability to repay its public debt (House \& Tesar, 2015). A decline of gross domestic product and the mentioned inability have been mitigated by the International Monetary Fund and the European Union, which 
have provided Greece with several loans. Therefore, the country had to implement several reform measures and start to save. The reforms in the fields of retirement and pensions and in the public administration, which showed signs of overemployment (Ardagna \& Caselli, 2014), were significant. Such steps did not meet understanding of the population and led to a huge wave of dissatisfaction across the country (Wang \& Bohn, 2018). A decrease of gross domestic product slowed down at the beginning of 2013, when the consequences of the reforms and the overall revitalisation of the national economy began to emerge. The unemployment rate, which reached the highest level among the European Union member countries in 2012 - a level of $27.3 \%$, began to slowly decline. In 2012, the level of inflation has shifted to the negative numbers in Greece. To a large extent, this development was influenced by the European Central Bank's policy, which in a view of the effects of the crisis tried to initiate the individual sectors of the economy and to get them out of the recession.

Since 2013, gross domestic product has remained at a steady constant level of around 180 billion EUR till now. Many economists predict that this phenomenon will last for several decades until the country reaches a pace of the gross domestic product growth like before the crisis. The challenge is the labour market, which has to solve long-term unemployment, an increasing number of young people without work, and the growth of people living on the brink of poverty (Kollintzas, Papageorgiou, Tsionas, \& Vassilatos, 2016).

A negative development of the macroeconomic indicators, loans from the International Monetary Fund, and foreign demand for fundamental reforms have led to great dissatisfaction of the electors. These ones accused the politicians and demanded a change in the country leadership in the wrong economic situation. The unstable economic and political situation led to the early election. Table 1 shows the chronological evolution of the past elections in Greece between 1996 and 2015.

Table 1. Overview of the election results from 1996 to 2015 (source: own elaboration by the authors according to Norsk senter for forskningsdata)

\begin{tabular}{|c|c|l|c|}
\hline Electoral term beginning & Year quarter & \multicolumn{1}{|c|}{ Winning political party } & Political spectrum \\
\hline 1996 & 3 & Panhellenic Socialist Movement & left wing \\
\hline 2000 & 2 & Panhellenic Socialist Movement & left wing \\
\hline 2004 & 1 & New Democracy & right wing \\
\hline 2007 & 3 & New Democracy & right wing \\
\hline 2009 & 4 & New Democracy & left wing \\
\hline 2012 & 2 & Panhellenic Socialist Movement & right wing \\
\hline 2015 & 3 & Coalition of the Radical Left & left wing \\
\hline
\end{tabular}

During the explored period, the four-year political cycle was fulfilled only in the two cases, from 1996 to 2000 and from 2000 to 2004. In these years, the Greek economy had been rising and all the indicators - gross domestic product, pensions, and employment in public administration had optimistic development. The electors perceived these facts positively. The 
positive development of these indicators was caused by the already high government expenditures, which instigated a disproportionate increase in the state deficit and public debt. Inadequate tax collection and high tax evasion were the problems too (Mavrogordatos, 2008). In 2009, information about the cases of the leader political party were made public. The most serious ones were the allegations of falsification of the data submitted to the International Monetary Fund and the European Union. Similarly, there were the dubious transactions via the Goldman Sachs Group investment bank, on the basis which Greece optically reduced the government indebtedness of. The unpopular reforms that the government party - the Panhellenic Socialist Movement - had to take led to the early elections and towards the win of the Coalition of the Radical Left party called Syriza. It initially refused these reforms. The 2016 year was the period of the negotiations and the agreements between the Greek government and their creditors on many austerity measures that ultimately have to get the country out of bankruptcy. This status has persisted till now. The Greek government has grasped the actual state of its economy and it gradually started to report the values of the individual macroeconomic indicators before the crisis.

Based on the findings of the macroeconomic and political situation of Greece, it is not possible to say whether it can be clearly defined one of the political-economic cycle types in the country. These characteristic signs are shown by the period from 1996 to 2007, when the politicians actually made interventions in the economy for the purpose of their re-election. Following the outbreak of the 2008 economic and financial crisis, the subsequent International Monetary Fund borrowing, the European Central Bank borrowing, and the forced implementation of the major reforms, the politicians have lost the space to manipulate the economic indicators in the period before the election. This is in the contrary to the politicaleconomic cycle theory. To confirm or deny the existence of the political-economic cycle in Greece, the econometric models are going to be developed to clarify this theory.

\section{Aim, data, and methodology}

The main objective of the contribution is to verify the existence of the political-economic cycle model of Greece and to determine the type of this cycle. For this purpose, the Alesina and Roubini (1992) methodology is selected. The reason for this selection is the fact that the authors of the study using their regression model simply test both the existence and the type of the political-economic cycle at the same time and are not limited to a certain type of a politically induced cycle. Based on this approach, the impact of policy cycles on employment, inflation and real gross domestic product is tested. The built-in econometric model lies in the autoregressive expression of the dependent variable. Subsequently, it is defined by the autoregression of a certain order and the insertion of a political variable, which always represents one of the theoretical concepts - one of the political-economic cycle type.

Formally, this relationship can be defined as follows (Alesina \& Roubini, 1992):

$$
y_{t}=\alpha_{0}+\alpha_{1} y_{t-1}+\alpha_{2} y_{t-2}+\ldots+\alpha_{n} y_{t-n}+\alpha_{n+1} P_{t}+\varepsilon_{t},
$$

where the involved variables mean: $t$ - the particular time period; $y_{t}$ - the explained variable in the $t$-th period; $\alpha_{0}$ - the constant value; $\alpha_{n}$ - the regression coefficient of the variable in 
the $n$-th period; $P_{t}$ - the political dummy variable in the $t$-th period; $\varepsilon_{t}$ - the residual in the $t$-th period.

The difference of the particular variable is marked by the $\mathrm{d}$ function with argument identified as the differentiated variable. The gross domestic product growth rate is marked $P$, the inflation rate $I$, and the unemployment rate $U$. The eight political-economic models are compiled using the combination of the macroeconomic data and the political data. The time series stationarity is tested using the Dickey-Fuller test. If necessary, the data differences are applied - the first ones or the second ones too. The Jarque-Bera test is employed to test whether residuals come from the normal probability distribution. The presence of heteroscedasticity is monitored by the Breusch-Pagan test. The Durbin-Watson test is used to detect serial correlation.

\subsection{Macroeconomic data}

The first of the dependent variables is gross domestic product. The growth rate of gross domestic product from the second quarter of 1995 to the fourth quarter of 2016 is applied. The second variable is the unemployment rate from the second quarter of 1998 to the fourth quarter 2016. The last dependent variable is inflation expressed by the Harmonised Index of Consumer Prices inflation rate from the second quarter of 1996 to the fourth quarter of 2016 which was recalculated from the monthly data. The quarter data from the Eurostat database is employed. According to the original study by Alesina and Roubini (1992), it is recommended to add an openness index of the economy, for instance the share of import and export in gross domestic product. Since the economy of Greece belongs to the economies that are characterised by a low level of openness. It means that a maximum share of $60 \%$ of the export and import of gross domestic product is realised in the economy. Hence, this variable is not included in the analysis. The creation of the political-economic cycle models is done in the $\mathrm{R}$ statistical environment.

\subsection{Political data}

The political data includes information on the term of elections, government change, and the change in political orientation of the government as outlined in Table 1. The definition of the political dummy variables for the individual political-economic cycle theories is based on the study of Janků (2013). When testing the Nordhaus political-economic cycle model, the political dummy variable named $P U$ is applied. This variable acquires a logical value of 1 in the quarter predecessing the quarter of the election term, as well as at the time of the election process. In the other periods, it gets a value of 0 . The $\mathrm{N}$ variable is elected taking into account the length of the likely pre-election expansion. Alesina and Roubini (1992) recommend to choose for the $\mathrm{N}$ variable values from 4 to 8 , which corresponds to one-year to two-year expansive pre-election policy. The rationally opportunistic models assume a change in an only one of the tested macroeconomic variables, namely inflation in the period after the election. In this case, the dummy variable PI is applied. It gets a logical value of 1 in the quarter of the election and in the four quarters following the election term. In the other periods, it acquires a value of 0 . The political variable $P I$ expresses an increased post-election 
inflation that is triggered by an expansive pre-election policy. The ideological theories of the political-economic cycle are mainly concerned with changing the political orientation of the government. Therefore, the value of the political dummy variable changes as a political focus of the government changes - whether it bears a right-wing direction or a left-wing direction. As Alesina and Roubini (1992) point out, the political change should be delayed for a period, because the new government have to have some time to implement its economic policy. In the case of unemployment testing, it is recommended that the policy variable is delayed by two periods, demonstrating the slow economic response to employment policy. The Hibbs model of the ideological cycle can be represented by the political variable $P P G$. This variable for real output and unemployment testing is consistently gaining a value of 1 in the period of the right-wing government and a value of -1 in the period of the left-wing government. In inflation testing, the political variable is assumed to be -1 during the entire left-wing government period and 1 for the right-wing government period. This policy variable is marked $P I_{t-1}$. The rational ideological models are represented the $P I$ variable. Because the rational ideological theories imply the temporary impact of a change in the government political orientation, the $P I$ variable increases by 1 in the $N$ quarters after the change of government for the right-wing direction and decreases by 1 when the government changes to the leftwing direction. In all the other periods, it gets a value of $0 . N$ is the same as in the previous case chosen from an interval from 4 to 8 . In the case of inflation, the permanent effects of a change of government are assumed, so the political variable is decreased by 1 in the period of the left-wing government and increased by 1 in the period of the right-wing government. This variable is marked $P I_{t-1}$ because it is identical to the political dummy variable used in the Hibbs model. An overview of the individual political variables is given in Table 2.

Table 2. Overview of the political dummy variables (source: own elaboration by the authors)

\begin{tabular}{|l|c|l|c|}
\hline \multicolumn{1}{|c|}{ Variable } & $\begin{array}{c}\text { Variable abbrevia- } \\
\text { tion }\end{array}$ & \multicolumn{1}{|c|}{ Model type } & $\begin{array}{c}\text { Quarter type with } \\
\text { another value }\end{array}$ \\
\hline Inflation rate & $P I$ & opportunistic & 5 \\
\hline Inflation rate lagged by 1 period & $P I_{t-1}$ & ideological & original value \\
\hline $\begin{array}{l}\text { Gross domestic product growth } \\
\text { rate }\end{array}$ & $P P G$ & opportunistic & 4 \\
\hline $\begin{array}{l}\text { Gross domestic product growth } \\
\text { rate lagged by 1 period }\end{array}$ & $P P G_{t-1}$ & ideological & 5 \\
\hline $\begin{array}{l}\text { Gross domestic product growth } \\
\text { rate lagged by 2 periods }\end{array}$ & $P P G_{t-2}$ & ideological & original value \\
\hline $\begin{array}{l}\text { Unemployment rate } \\
\text { Unemployment rate lagged by 1 } \\
\text { period }\end{array}$ & $P U_{t-1}$ & ideological & 4 \\
\hline $\begin{array}{l}\text { Unemployment rate lagged by 1 } \\
\text { period }\end{array}$ & $P U_{t-1}$ & ideological & original value \\
\hline
\end{tabular}




\section{Political-economic cycle models of economy of Greece}

For the purpose of meeting the goal of the contribution, the eight political-economic cycle models are created (Papp, 2017). Sequentially, the different individual political variable enters the separate models and also the dependent variable too. There are separately explored the opportunistic and ideological models in the individual subchapters.

\subsection{Opportunistic model with the dependent variable unemployment rate}

The first model is a linear model with the dependent variable expressing unemployment and with the political dummy variable $P U$. The delay of the dependent variable is determined gradually by four periods, which means one year. To ensure the stationarity of the time series, the second differences are applied.

The final equation of the regression model has the following form:

$$
\begin{gathered}
d(d(U))=-0.05216-0.42967 d\left(d\left(U_{t-1}\right)\right)-0.15815 d\left(d\left(U_{t-2}\right)\right)+ \\
0.08322 d\left(d\left(U_{t-3}\right)\right)+0.15007 d\left(d\left(U_{t-4}\right)\right)+0.1124 P U
\end{gathered}
$$

The adjusted coefficient of determination reaches a value of 0.1141 , meaning that only $14.11 \%$ of the total variability is explained by the model. At the same time, the $p$-value of the $F$-test is less than the 0.05 significance level, which points to rejection of the null hypothesis $\mathrm{H}_{0}$ stating that the model as a whole is not statistically significant. During testing residuals, the Jarque-Bera test $p$-value stands at a level of 0.03 resulting in rejecting the null hypothesis $H_{0}$. It suggests that the residuals do not come from the normal probability distribution. Also, there is no heteroscedasticity and serial correlation. Looking at the political dummy variable and its regression coefficient, it can be stated that p-value is not significant at the five-percent significance level. This expresses that the theories of the opportunistic models could not be confirmed, thus demonstrating that in the period before the election, the unemployment rate is purposefully influenced.

\subsection{Opportunistic model with the dependent variable gross domestic product growth rate}

For a need of the model with the dependent variable gross domestic product, the same political dummy variable $P P G$ and the four-period lag of the dependent variable is applied. The base time series of gross domestic product is non-stationary. Therefore, the first differences are applied. The residual normality test indicates the invalidity of the null hypothesis meaning that residuals come from the normal probability distribution. After thorough analysis, the lagged gross domestic product variables lagged by three and four periods are avoided. Their discarding does not make a significant change. On the contrary, the coefficient of determination increases after this step. By removing these variables, the problem of heteroscedasticity is eliminated, serial correlation is not present too.

The final regression model equation has a subsequent form:

$$
d(P)=-0.04583-0.90602 d\left(P_{t-1}\right)-0.44426 d\left(P_{t-2}\right)+0.08718 P P G .
$$


The model as a whole is statistically significant. The adjusted coefficient of determination has a value of 0.4952 , indicating that the total variability is expressed at a level of $49.52 \%$. However, this is not a guideline in the analysis, as it is particularly important what characteristics the political variable has. In a more rigorous analysis, it observed a significantly higher $\mathrm{p}$-value for the political dummy variable the significance level is. This situation suggests that the opportunistic theory itself, on the basis of which gross domestic product is affected before the election to be re-elected again, is not valid. If this political variable is statistically significant, a positive sign suggests that gross domestic product would develop in a line with the opportunistic theory and therefore, it would increase gross domestic product in the period before the election.

\subsection{Opportunistic model with the dependent variable inflation rate}

The third observed variable is inflation rate. In this model, the political dummy variable PI is involved to express the impact of the election term on the inflation rate for the opportunistic theories. The same time series tests are performed. The base time series is non-stationary, but this disease is eliminated by an application of the first differences.

The mathematical equation of the model is constructed as follows:

$$
\begin{gathered}
d(I)=-0.0313-0.81233 d\left(I_{t-1}\right)-0.62122 d\left(I_{t-2}\right)-0.61026 d\left(I_{t-3}\right)- \\
0.01253 d\left(I_{t-4}\right)-0.22851 P I_{t-1} .
\end{gathered}
$$

The determination factor is 0.5667 in this case. The F-test p-value is less than the significance level of $5 \%$, which allows the rejection of the null hypothesis suggesting the model as a whole is not statistically significant. Residuals are come from the normal probability distribution and heteroscedasticity with serial correlation are not present in the model. The political dummy variable p-value is, as in the previous cases, higher than the significance level. This confirms the invalidation of the theory that, in the post-election period, the inflation rate rises as a result of an expansive economic policy before the election. If the political variable is statistically significant, a negative sign will mean that, in the post-election period, the inflation rate declines on the contrary, which is also in a contradiction with the opportunistic theory.

\subsection{Ideological models with the dependent variable unemployment rate}

As with opportunistic models, the second differences for the variable unemployment rate are applied. The input is created by the political dummy variable PU lagged by one period and the political dummy variable of the Hibbs ideological model PU lagged by two periods. The both are lagged by two periods. Using the first political variable RPT, the adjusted coefficient of determination is only at a level of 0.15 , but the model as a whole is statistically significant according to the F-test. Residuals are not from the normal probability distribution, but heteroscedasticity with serial correlation are absent. The political dummy variables are not significant at the five-per-cent significance level. Hence, it can be said that the theory of the ideological political-economic cycle can be confirmed. The results using the second 
mentioned variable are very similar. The only difference is that residuals come from the normal probability distribution. The political dummy variable is also statistically insignificant.

The mathematical equations of the model involving the political dummy variable PU looks like as follows:

$$
\begin{gathered}
d(d(U))=-0.008885-0.47918 d\left(d\left(U_{t-1}\right)\right)-0.234033 d\left(d\left(U_{t-2}\right)\right)+ \\
0.029037 d\left(d\left(U_{t-3}\right)\right)+0.121973 d\left(d\left(U_{t-4}\right)\right)-0.080732 P U_{t-1} .
\end{gathered}
$$

The second model involving the political dummy variable PU is constructed subsequently:

$$
\begin{gathered}
d(d(U))=-0.01343-0.44305 d\left(d\left(U_{t-1}\right)\right)-0.18146 d\left(d\left(U_{t-2}\right)\right)+ \\
0.07773 d\left(d\left(U_{t-3}\right)\right)+0.14183 d\left(d\left(U_{t-4}\right)\right)-0.01896 P_{t-2} .
\end{gathered}
$$

\subsection{Ideological models with the dependent variable gross domestic product}

There are again the two political variables marked PPG with a one-period lag or a two-period lag in the ideological models with the dependent variable gross domestic product. In this case, the first differences of gross domestic product are applied. The coefficient of determination is at a level of 0.5 , but in the process of further testing, heteroscedasticity is detected. This disease is removed by eliminating the gross domestic product variable lagged by four periods. The value of the political dummy variables remained at a statistically insignificant level. Serial correlation is not present, but residuals show a non-normal probability distribution origin. It is not possible to prove the validity of the ideological political-economic cycle theory. This is justified by the statistical significance of the political dummy variable, which is not statistically significant at the level of significance of $5 \%$.

The regression model with the political dummy variable $P P G_{t-1}$ is subsequent:

$$
\begin{gathered}
d(P)=-0.02166-0.87776 d\left(P_{t-1}\right)-0.39014 d\left(P_{t-2}\right)+ \\
0.05292 d\left(P_{t-3}\right)-0.01248 P P G_{t-1} .
\end{gathered}
$$

The second model involving the political dummy variable $P P G_{t-2}$ is constructed subsequently:

$$
\begin{gathered}
d(P)=-0.01658-0.87414 d\left(P_{t-1}\right)-0.38751 d\left(P_{t-2}\right)+ \\
0.05339 d\left(P_{t-3}\right)-0.10206 P P G_{t-2} .
\end{gathered}
$$

\subsection{Ideological model with the dependent variable inflation rate}

The last one of the explored models is the ideological political-economic cycle model with the dependent variable inflation rate. Here, the political variable $P I_{t-1}$ is lagged by one period. Just as with the previous models, it is based on the stationary time series that is achieved using the first differences. The adjusted coefficient of determination with a value of 0.5589 reflects the fact that the overall variability is expressed by a portion of $55.89 \%$. The p-value of 
the F-test is lower than the significance level, indicating that the model as a whole is statistically significant. Heteroscedasticity and autocorrelation are not present and residuals come from the normal probability distribution.

The model looks like as follows:

$$
\begin{gathered}
d(I)=-0.055702-0.794111 d\left(I_{t-1}\right)-0.607165 d\left(I_{t-2}\right)- \\
0.600134 d\left(I_{t-3}\right)-0.003907 d\left(I_{t-4}\right)+0.074638 P I_{t-1} .
\end{gathered}
$$

\section{Summary of the outcome of the opportunistic and ideological models}

Applying the interpretations of the outcome of the previous three opportunistic models, it can be stated that none of the political variables demonstrate statistical significance at the selected significance level. The opportunistic political-economic cycle theory of gross domestic product, unemployment and inflation in the run-up to re-election are not confirmed. For the needs of a more detailed analysis, a change in the type of the data entering into the model is also performed, as well as the Hodrick-Prescott filter is applied to separate the trend component of the data from the cyclic component (Kovacic \& Vilotic, 2017). Even though, it does not lead to the positive outcome. The model as a whole is statistically significant, so the cause of this result has to originate somewhere else. This is due to the significant problems that Greece faces both the issues in the macroeconomic terms as well as the political terms. The development of the individual macroeconomic indicators is strongly influenced by many external and internal effects. Politicians are forced to implement certain measures and reforms, irrespective of the date of the elections, due to the linking of these reforms to the aid packages already provided. Likewise, the often repeated non-observance of the electoral term shortens the political cycle in the country, and it is very challenging for politicians to plan such activities that would increase their re-election possibility. The summarisation of the comprised regression models is demonstrated in the following Table 3.

Table 3. Overview of the regression models

\begin{tabular}{|c|l|l|l|}
\hline Model & \multicolumn{1}{|c|}{ Model type } & \multicolumn{1}{c|}{ Dependent variable } & \multicolumn{1}{|c|}{ Theory } \\
\hline 1 & opportunistic & unemployment rate & not confirmed \\
\hline 2 & opportunistic & gross domestic product growth rate & confirmed \\
\hline 3 & opportunistic & inflation rate & not confirmed \\
\hline 4 & ideological & unemployment rate & confirmed \\
\hline 5 & ideological & unemployment rate & confirmed \\
\hline 6 & ideological & gross domestic product growth rate & not confirmed \\
\hline 7 & ideological & gross domestic product growth rate & not confirmed \\
\hline 8 & ideological & inflation rate & not confirmed \\
\hline
\end{tabular}


In the case of the ideological models as well as in the case of the opportunistic models, it is possible to conclude that the political-economic theory cannot be confirmed. As in the first case, this outcome can be assigned to the others factors than the econometric factor. The produced models as a whole are statistically significant, except for some instances. They are represented by the good values of the adjusted coefficients of determination, and neither heteroscedasticity nor serial correlation are present in them. The ideological models relate to the changes in the economic policy according to membership of the political party, which should lead to re-election. Regardless of political affiliation, the ruling parties in Greece have to apply explicitly opposite measures in comparison with the basement of the both ideological and opportunistic political-economic models. The biggest limitation of the research is the length of the time series of the input data. Several facts about the length of the electoral period, the manifestations of the financial and economic crisis and some other aspects also influence the final result.

\section{Conclusions and discussion}

The political and economic situation has been one of the most important areas of interest for the economy sector, the financial sector and above all for the international institutions in Greece in the recent years. Greece, as a member of the European Union and the euro area, has created the excellent conditions for economic growth and economic development. The economic cycle of the country has developed positively, representing the reported gross domestic product growth and the associated increase of employment rate. On the other hand, this was accompanied by a disproportionately high growth in government spending, an increase in the government deficit and the public debt. The political situation in the country was stable mainly due to the manipulation of the macroeconomic indicators by politicians. The Greek economy showed signs of a political-economic cycle existence. The closest to this is the Nordhaus model based on the opportunistic basement with non-rational voters.

The main objective of the contribution is to verify the existence of the political-economic cycle model of Greece and to determine the type of this cycle. For this purpose, an Alesina and Roubini (1992) approach is selected. Based on the analysis of the macroeconomic and political situation of the Greek economy, it could be presumed that there is also a politicalbudgetary cycle in the country, which is reflected in an excessive increase in the government deficit and public debt. This assumption would need to undergo a deeper analysis. There were the significant changes in the behaviour of the political parties after 2008. They have manifested themselves in the implementation of unpopular reforms that followed the adoption of the several bailouts for the country. Hence, the political parties start to behave in the contrary to the political-economic cycle theory. They even implement the opposite policy, which can lead and ultimately leads to early election and the change of the leading political parties. They are continuing in these reforms despite the possible future failure in the next election.

The political and economic situation since 1996 to 2016 points to the absence of the political-economic cycle. This assumption is tested in the form of the linear regression models in the R statistics environment. These models demonstrate the invalidity of the opportunistic 
and ideological models of the political-economic cycle in Greece. Several early elections and the external influences in the form of the global financial crisis contributes to this result. It is likely that the political-economic cycle would be confirmed in the period from 1996 to 2008 .

The international comparison with the other countries is very difficult. It is caused by the several facts. The most significant one is the fact that the political-economic cycle is specific for each country. Although there are some countries that suffer from the similar diseases as Greece, it would be very difficult to generalise the outcome.

In the case of the political-economic cycle theory, it is also important to keep an eye on the fact whether its presence in the real world is desirable. A politician elected by citizens should decide for the benefit of the both present and future generations of the country population. This politician should not only follow the cycle of re-election in the next election. For this reason, politician have to develop the long-term country development strategies that should go beyond the political cycle and would be implemented regardless of the political affiliation of the winning party. However, this is an ideal situation which is unlikely due to the nature of politician. Perhaps there is an alteration in the nature of the voter, which should change behaviour from irrational to rational. In this case, the voter can estimate that the politician manipulates the results of the economy for re-election purposes. This presupposes the sufficient knowledge of the voter about the economic situation of the country and its forecasts. Such a voter can accept and support the political parties which prefer the reforms. In this context, it would be interesting to see how the Greek political cycle would evolve and whether the current political parties that are forced to reform will continue to be popular in the future.

The ideal rational voter should also estimate the presence of the hidden political-budget cycle. Drazen and Elseva (2010) point out that politicians can shift government spending from one area to another without affecting the government deficit and the government debt. An example may be an increase in pensions or the support of the low-income part of the population - those who form the electoral base of the political party to the detriment of the other areas of the public finances. It is important to note that a major advantage in such a political struggle is kept the ruling party that implements its own political support through the public spending.

\section{Author contributions}

AT prepared the concept of the paper, AT and BG constructed the literature review, AT and VK suggested the methodology, BG and VK carried out the analysis, AT, BG and VK prepared the discussion and the conclusions, BG and VK revised the paper finally. The other remaining activities were done proportionally by all the three authors.

\section{Disclosure statement}

The authors have no competing financial, professional, or personal interests from other parties. 


\section{References}

Alesina, A. (1987). Macroeconomic policy in a two-party system as a repeated game. The Quarterly Journal of Economics, 102(3), 651-678. http://doi.org/10.2307/1884222

Alesina, A., \& Roubini, N. (1992). Political cycles in OECD economies. Review of Economic Studies, 59(4), 663-688. http://doi.org/10.2307/2297992

Alesina, A., \& Sachs, J. (1988). Political parties and the business cycle in the United States, 1948-1984. Journal of Money, Credit and Banking, 20(1), 63-82. http://doi.org/10.2307/1992667

Alt, J. E., \& Lassen, D. (2006). Transparency, political polarization, and political budget cycles in OECD countries. American Journal of Political Science, 50(3), 530-550. http://doi.org/10.1111/j.1540-5907.2006.00200.x

Ardagna, S., \& Caselli, F. (2014). The political economy of the Greek debt crisis: A tale of two bailouts. American Economic Journal: Macroeconomics, 6(4), 291-323. http://doi.org/10.1257/mac.6.4.291

Brender, A., \& Drazen, A. (2005). Political budget cycles in new versus established democracies. Journal of Monetary Economics, 52(7), 1271-1295. http://doi.org/10.1016/j.jmoneco.2005.04.004

Calvo, E., Chang, K., \& Hellwig, T. (2017). The valence gap: Economic cycles, perceptions of competence, and the party system. Electoral Studies, 45, 163-172. http://doi.org/10.1016/j.electstud.2016.10.008

Chrysanthou, G. M., \& Guilló, M. D. (2018). The dynamics of political party support and egocentric economic evaluations: The Scottish case. European Journal of Political Economy, 52, 192-213. http://doi.org/10.1016/j.ejpoleco.2017.06.003

Drazen, A. (2000). The political business cycle after 25 years. In National Bureau of Economic Macroeconomics Annual 2000, 15, 75-138. Retrieved from http://www.nber.org/chapters/c11055

Drazen, A., \& Eslava, M. (2010). Electoral manipulation via voter-friendly spending: Theory and evidence. Journal of Development Economics, 92(1), 39-52. http://doi.org/10.1016/j.jdeveco.2009.01.001

Galeotti, A., \& Salford, G. (2001). Electoral cycles: Do they really fit the Data? (Tinbergen Institute Discussion Paper 01-076/1). Retrieved from http://hdl.handle.net/10419/85793

Garmann, S. (2017). Political budget cycles and fiscally conservative voters. Economic Letters, 155, 7275. http://doi.org/10.1016/j.econlet.2017.03.023

Haan, J., \& Klomp, J. (2013). Conditional political budget cycles: a review of recent evidence. Public Choice, 157(3-4), 387-410. http://doi.org/10.1007/s11127-013-0106-6

Hibbs, D. (1977). Political parties and macroeconomic policy. The American Political Science Review, 71(4), 1467-1487. http://doi.org/10.2307/1961490

House, C. L., \& Tesar, L. L. (2015). Greek budget realities: No easy option. Brookings Papers on Economic Activity, Fall, 329-347. http://doi.org/10.1353/eca.2015.0002

Janků, J. (2013). Politicko-ekonomický cyklus v ČR. Ekonomická revue - Central European Review of Economic Issues, 16(3), 121-130. Retrieved from http://www.ekf.vsb.cz/export/sites/ekf/cerei/cs/ cisla/vol16/vol16num3/dokumenty/VOL16NUM03PAP02.pdf

Janků, J. (2016). Podmíněný politicko-rozpočtový cyklus v zemích OECD. Politická Ekonomie, 64(1), 65-82. http://doi.org/10.18267/j.polek.1055

Kliková, Ch., \& Kotlán, I. (2006). Hospodářská politika. Ostrava: Sokrates.

Klomp, J., \& Haan, J. (2013). Political budget cycles and election outcomes. Public Choice, 157(1-2), 245-267. http://doi.org/10.1007/s11127-012-9943-y

Kollintzas, T., Papageorgiou, D., Tsionas, E., \& Vassilatos, V. (2016). Market and political power interactions in Greece: An empirical investigation (Working Paper Series 6-2016). Athens University of Economics and Business. http://doi.org/10.2139/ssrn.2819004 
Kovacic, Z. J., \& Vilotic, M. (2017). Characterising and testing European business cycles asymmetry. Equilibrium - Quarterly Journal of Economics and Economic Policy, 12(3), 453-468. http://doi.org/10.24136/eq.v12i3.24

Mavrogordatos, G. T. (2008). Greece. European Journal of Political Research, 47(7-8), 990-997. http://doi.org/10.1111/j.1475-6765.2008.00794.x

Mura, L., \& Machyniak, J. (2014). Ethical aspects of public administration. Hradec Economic Days 2014, 4(2), 59-65.

Musgrave, R. A. (1994). Veřejné finance v teorii a praxi. Praha: Management Press.

Nordhaus, W. (1975). The political business cycle. The Review of Economic Studies, 42(2), 169-190. http://doi.org/10.2307/2296528

Norsk senter for forskningsdata. Greece - Parliamentary Elections. Retrieved from http://www.nsd.uib. no/european_election_database/country/greece/parliamentary_elections.html

Papp, P. (2017). Modely politicko-ekonomického cyklu a ich testovanie v podmienkach vybranej krajiny.

Patrikios, S., \& Karyotis, G. (2008). The Greek parliamentary election of 2007. Electoral Studies, 27(2), 356-359. http://doi.org/10.1016/j.electstud.2007.12.004

Persson, T., \& Tabbelini, G. (2002). Political Economics: Explaining Economic Policy. Southern Economic Journal, 68(3), 738-742. http://doi.org/10.2307/1061733

Půbal, K., \& Vítek, L. (2003). Testování vlivu termínu voleb na vývoj míry inflace během transformace zemí Visegrádu. Centre for New Institutional Studies.

Rogoff, K. (1990). Equilibrium political budget cycles. The American Economic Review, 80(1), 21-36.

Rogoff, K., \& Sibert, A. (1988). Elections and macroeconomic policy cycles. The Review of Economic Studies, 5(1), 1-16. http://doi.org/10.2307/2297526

Shi, M., \& Svensson, J. (2002). Conditional Political Budget Cycles. (Centre for Economic Policy Research Discussion Paper No. 3352). Centre for Economic Policy Research.

Shi, M., \& Svensson, J. (2006). Political budget cycles: Do they differ across countries and why?. Journal of Public Economics, 90(8-9), 1367-1389. http://doi.org/10.1016/j.jpubeco.2005.09.009

Štiková, R. (2007). Modely politického cyklu a jejich testováni na podmínkách ČR (Institute of Economic Studies Working Paper No. 18). Institute of Economic Studies. Retrieved from http://ies.fsv.cuni. cz/default/file/download/id/5618

Tujula, M., Wolswijk, G. (2007). Budget balances in OECD countries: what makes them change?. Empirica, 34(1), 1-14. http://doi.org/10.1007/s10663-006-9015-y

Villarreal, C. C., \& Bielma, L. H. (2017). Economic integration, economic crises and economic cycles in Mexico. Contaduría y Administración, 62(1), 85-104. http://doi.org/10.1016/j.cya.2016.01.006

Wang, X., \& Bohn, F. (2018). Pension reserve fund, political budget cycles and fiscal illusion. European Journal of Political Economy, in press. http://doi.org/10.1016/j.ejpoleco.2018.07.002 